\title{
Perceptions and Behavior's of Muslims and Non-Muslims towards Halal Products
}

\author{
*Maisarah Ahmad, Suhaila Abdul Kadir, Nurul Azida Salehuddin \\ National University of Malaysia UKM Bangi Selangor, Malaysia \\ *sara@ukm.my
}

\begin{abstract}
This study aims to determine the level of acceptance and perception and behavior of the Muslim and non-Muslim toward halal products. This study is based on a survey of 300 respondents randomly selected. Data collected using questionnaires. Consumer behavior towards the adoption of available products is high and it is found that consumers are very highly concerned about food preparation factors are ordered from legitimate sources. In general, the frequency of residents in Lembah Pantai visiting the restaurant is every day namely working respondents. In addition, the cleanliness of the restaurant is one of the factors influencing the selection of respondents in regular restaurants. However, the results showed that the respondents were not so concerned with the cleanliness factor as long as the restaurant food was available to be served from legitimate sources and clean. The study concluded that restaurant operators should emphasize the preparation of food from halal sources and ingredients to the customers. Either recommendation has been made to the owners of restaurants to prioritize sanitation in the restaurant or involving the workers themselves to ensure hygiene is always guaranteed. Government agencies to tighten the licensing and regulation of halal logo to restaurant operators to ensure that the use of food ingredients is completely clean, pure and halal.
\end{abstract}

Keywords: Muslim, Non-Muslim, halal product, cleanliness of restaurant, employee

\section{Introduction}

The issue of purity of a product or service is sensitive to the Muslim community (CAP, 2006). Subsequently, each selected food must be guaranteed clean in accordance with Islamic law (Utusan Malaysia, May 5, 2008). For consumers, the issue of selection of the halal products must be emphasized. According to Mohani et al. (2009), the decision-making process for the Muslims is very important in buying these products. Even the non-Muslim is no exception in this regard. Golnaz et al. (2010) found that non-Muslims are aware of halal principles and try to raise the level of awareness through advertising published in halal products. They feel that halal products are clean and pure from dirt and will not cause harm to them. Therefore, Muslim users should be aware of several things about the products such as source, process, packing, storage and production. Users also should have the curiosity before buying foreign products even though it has the indication of halal (Berita Harian, July 30, 2005). Consumers' awareness towards the selection of halal, clean and pure is rising up from the increase in malpractice cases against goods in the market (Engku Norma, 2009). For this reason, consumers are becoming more cautious as there are unscrupulous traders and are only concerned with profit alone without considering the sensitivity of Muslim consumers (Berita Harian, May 9, 2006). However, there are still users who have poor awareness of the demand for halal products in the local market. This is due to lack of awareness and knowledge of the importance of halal products (Utusan Malaysia, 29 Sept 2012). Hence, it is important to carry out this research in order to determine the level of acceptance and awareness of halal products used.The paper is organized as follows: Section II discusses literature review, Section III describes research methodology, Section IV addresses statistical results, Section V highlights the discussion, and Section VI provides conclusion and recommendations of the study.

\section{Literature Review}

Theory of Planned Behavior: Theory of Planned Behavior is the sequence to TRA, which is taking into account the control of behavior seen. According to this theory, a person will only perform his intention when he feels able to control the implementation of the action. The perceived control is different according to the perception of behavioral complexity. This perception is based on the reflection of a person's experiences and obstacles or barriers to perform the behavior. Ajzen et al. (1980) concluded that the importance of perceived control is to determine the relationship between attitudes and behavior has been demonstrated in a number of empirical studies. This study supported the hypothesis stated that those with high control will have a strong intention to perform certain behavior and will do so when it is 
deemed appropriate. Therefore, this theory was applied in this study in order to know the behavior of consumers in making food-purchasing decisions in ordinary restaurants. It is divided into three behavioral variables such behavior to make a purchase, intention to make purchase and subjective norm. Below is the model showing how the behavior of one towards the acceptance of halal products.

Figure 1: The model shows the relationship between the dependent variable and the independent variables

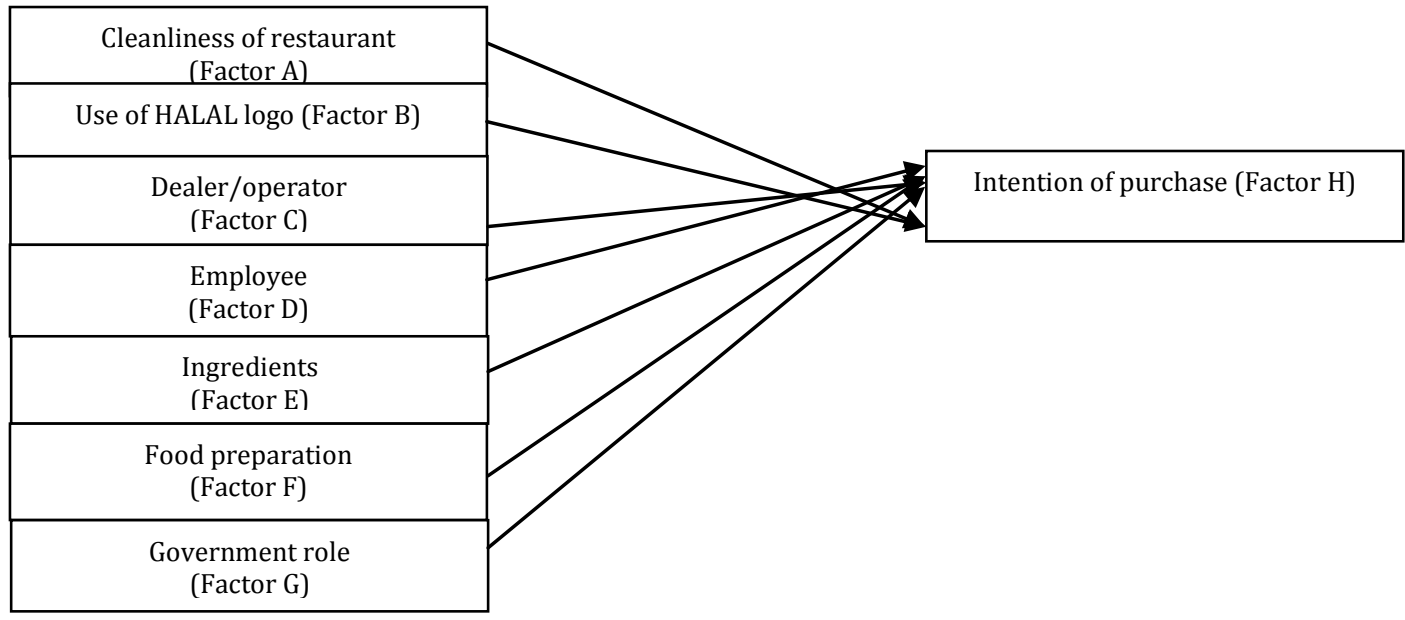

Based on the model above, it can be classified into attitude and awareness towards the halal concept. It is divided into variables such as the use of the halal logo displayed in the restaurant and the role of government plays in giving permission for the establishment of typical restaurants. These attitudes and awareness can be shown by the respondents on the questions posed in the questionnaire. While, for item of subjective norms namely the perception of someone regarding social pressure for commit or not commit behavior Ajzen (1980), variables that can be classified under this item are food preparation and also cooking ingredients. They are some of the things that are important to customers to enjoy a meal that has been ordered. Through these variables, it can be seen the behavior of respondents for their willingness to enjoy the food cooked by the chefs in the restaurants. Next for the item of control perception behavior, it can be classified under variable of dealer or restaurant operators, employees and cleanliness of the restaurant. Out of these variables, it can be seen through the behavior of respondents who came to the restaurant to enjoy the food. These factors will influence the respondents' acceptance of halal products especially in common restaurant and the importance of customer comfort while enjoying the meal. According to Syed (2011), the planned behavior theory model conducted by Ajzen et al. (1980) have relevance in conducting decisions and effective to forecast the expected purchases by the use of halal food in Malaysia. This statement is in line with the study by Sudin et al. (2009), who found that through this theory, it proves that an individual decision to buy halal products is based on individual behavior and attitudes, subjective norms and perceptions of consumers. This theory turns out to be in line with the behavior, attitudes and perceptions of different individuals to each other and can predict the intention to choose halal products among consumers in Malaysia. According to Syed (2011), the theory of planned behavior is effectively predicting the expected halal food purchases by the Malaysian consumer and government power. Therefore, halal food manufacturers should focus on creating social expectations towards the purchase of halal products and improving consumers' desire to buy lawful food.

Cleanliness of restaurant: Abdul Basit \& Sahilah (2010) in their study of the perception of halal buyers found that the student's interests also include the purchase of halal products. They will not make a purchase at the premise belongs to non-Muslims due to the concern that it is unlawful, harmful to health. Golnaz (2009) gave similar view when he said that Muslim consumers having high level of religiosity is very concerned about the manufacturing of halal products and concerned about this matter to ensure that the products purchased by them are lawful. Cleanliness is an essential quality for acquiring halal status of processed food (Dayang Aniza, 2012). Unfortunately, some restaurants are in dirty conditions and failed to meet hygiene standards that have been set. For example, the refrigerator is in dirty conditions with uncontrolled temperature, irregular waste disposal system and clogged. Based on this review, this study proposed the following hypothesis.

$\mathrm{H}_{1}$ : There is a significant relationship between cleanliness of restaurant and intention of purchase 
Use of HALAL logo: While Arshia \& Muhammad (2011) in their study in Pakistan found that although users adhere to the teachings of Islam and religious beliefs practiced by them, not necessarily that they are aware that the food sold is lawful or otherwise. Apart from the awareness of Muslim on halal products, consumers also expect availability of the use of the halal logo on food packaging so as not to cast doubt (Mohani et al., 2009). Therefore, the authorities must tighten the laws to ensure that the halal logo can be standardized in order to avoid confusion to Muslims.

$\mathrm{H}_{2}$ : There is a significant relationship between the use of Halal logo and intention of purchase

Dealer/operator: In general, this study aims to determine the level of acceptance and perception and behavior of Muslims and non-Muslims for halal products. Considering that the issue of product purity is very important especially for Muslim consumers, it is therefore necessary to carry out studies to identify the perceptions and behavior of Muslim on halal products. In addition, the government also plays a very important role in granting of halal licenses and certificate to restaurant operators (Abdul Basit \& Sahilah, 2010).

$\mathrm{H}_{3}$ : There is a significant relationship between dealer/operator of restaurant and intention of purchase

Employee: According to Dayang Aniza (2012) among the reasons that a restaurant is not certified with halal certification is because the workers do not practice good hygiene when handling the aspects of food and beverage. Therefore, employees should be responsible for ensuring the neatness of clothing and hygiene at all times, including ensuring refreshing body odor and ironed clothes (KPDNKK, 2013).

$\mathrm{H}_{4}$ : There is a significant relationship between employee of restaurant and intention of purchase

Ingredients: Therefore, awareness of Muslim on halal products is very important in ensuring that they get halal and clean products. Study done by Faryal \& Kamran (2011) found that Muslims are more concerned and looking for halal products through the elements found in food items. The assurance of Halal of a food product is from the beginning process of determining food raw materials, the process of preparing food until it is ready to serve. This process involves the practice of hygiene, use of halal ingredients, equipment and food and beverage operations. Unfortunately, there are restaurant owners who do not take into account such aspects (Dayang Aniza, 2012). Besides that, there are also restaurants that have used food ingredients like soy sauce without the halal logo, using alcohol as a food ingredient and food handling processes that do not meet the halal concept. This causes difficulty for JAKIM to approve their halal application.

$\mathrm{H}_{5}$ : There is a significant relationship between ingredients and intention of purchase

Food preparation: Provision of halal food in food premises usually involves the principles and obligations of a Muslim himself. In addition, the lawful of a food can be maintained by taking into account aspects of the ingredients used as well as maintaining personal hygiene, cleanliness and safety in food products (Dayang Aniza, 2012). Halal food will be illegal if mixed with non-halal food.

$\mathrm{H}_{6}$ : There is a significant relationship between food preparation and intention of purchase

Government role: However, Mohd Riozaimy et al. (2010) on the contrary considered that the religious factor is something that does not need to concern by consumers because it is the government policy to issue the halal certification and product authorized by permit. Lili (2006) supported this opinion in his study that found that the influence of halal cosmetics products Wardah proved that halal does not become the most important factor in purchasing a product because consumers consider the use of the halal logo is tasked by the government to ensure that it is safe to be used. This showed the importance of the role of the authorities in ensuring the halal logo and certification can be tightened and adjusted to reduce the level of concern of either Muslim or non-Muslim consumers (Abdul Basit \& Sahilah, 2010). $\mathrm{H}_{7}$ : There is a significant relationship between government role and intention of purchase

\section{Methodology}

Study sample: This study was carried out based on surveys. The subjects consisted of 300 respondents selected randomly by focusing on the people around Bangsar Utama, Bangsar Baru, Pantai Dalam, Kg Kerinchi and Jalan Travers. Data collected from respondents through a questionnaire taken from previous studies (Abdul Basit \& Sahilah 2010; Mohani et al. 2009; Syed Shah Alam 2011; Faryal \& Kamran 2011 and Golnaz et al., 2009). Questionnaire contained several items that measured the acceptance factors of halal products and the respondents' views and recommendations of halal products to restaurant operators as well as to the overall restaurant visited by the respondents. 
Instrument and Development: To determine the validity, the questionnaire was revised and the coefficients of Cronbach Alpha .78 was obtained to measure the reliability of the acceptance factors of the halal product. The questionnaire used in this study consisted of three sections. The first section or Part A contained demographic information. The second section or Part B consisted of the acceptance factors of halal products. Respondents' acceptance factors of halal products were measured using 17 items, which were cleanliness of restaurant, ingredients, use of halal logo, restaurant employee's, dealer/operator, food preparation, government role and intention of purchase. Cleanliness of restaurant was measured based on respondent's perception on cleanliness of the restaurant that attracts them to buy or dining. The use of Halal logo measured the extent of restaurant owner to use logo halal in their restaurant. Meanwhile, the scale has measured the dealer/operator of restaurant based on chef of the restaurant. Employees' restaurant was measured based on the employee's efficiency in order to ensure the pristine condition in the restaurant. To measure the respondent's perception on ingredients used to cook food, this scale measured the respondent's perception of the content and material resources in cuisine, either halal or non-halal. Food preparation was measured based on respondent's perception about equipment and hygienic food during preparation. The government role was measured based on the in coordinated halal logo and tightening laws in restaurant operation. Finally, the scale was also measured the intention of purchase of the respondent by searching for additional information before making a purchase at the restaurant. In Part C consisted of respondents' views and recommendations of halal products to restaurant operators as well as to the overall restaurants visited by the respondents. Likert scale options of 5 have been used to measure the acceptance factors of halal products which were ' 1 ' indicated strongly disagree to '5' indicated strongly agree. Data were analyzed descriptively using SPSS package to determine the demographic factors conducted. Pearson correlation analysis was also conducted to analyze the correlation between the variables (Tabachnick et al, 2001; Yaacob, 2008). Eventually, Stepwise regression analysis was used to test the hypothesis as it can assess the magnitude of each independent variables and dependent variables (Baron \& Kenny, 1986; Foster et al,. 1998).

\section{Results}

Profile of respondents: Table 1 shows the profile of the respondents. Clearly visible that $53.0 \%$ of the respondents were female while $47.0 \%$ of them were male respondents. A total of $24.0 \%$ of respondents aged between $21-25$ years, followed by $18.0 \%$ of respondents who were aged between $46-50$ years. While, only $3.7 \%$ of respondents aged between $36-40$ years. The study also found that as many as $71.0 \%$ of the respondents were private employees, followed by $17.7 \%$ of respondents were students, while $6.0 \%$ were government employees and only $5.3 \%$ of respondents were unemployed. In terms of marital status, a number of $67.0 \%$ of respondents were married, followed by $30.7 \%$ of respondents who were single and $2.3 \%$ of the respondents were divorced. Table 1 also shows that $23.7 \%$ of respondents have a family income of RM > 4001, followed by $23.7 \%$ of respondents with an income between RM 3001-RM 4000 . While, only $7.0 \%$ of respondents with family income less than RM 1000. If observed in terms of race, a total of $58.3 \%$ of the respondents were Malays, followed by $22.0 \%$ of respondents were Chinese, $19.0 \%$ of them were Indian respondents and other races were 7\%. Similarly, in term of religion, the majority of respondents were predominantly Muslims recorded 59.0\%, followed by $19.0 \%$ of respondents were Buddhist, $14.3 \%$ of respondents were Hindus and $7.7 \%$ of the respondents were Christian. In terms of frequency of visiting the restaurant, about $28.0 \%$ of the respondents visited every day, followed by $19.3 \%$ of respondents visiting once a week, $18.7 \%$ respondents have visited twice a week and $9.7 \%$ of respondents visit thrice a week. 
Table 1: Profile of respondent

\begin{tabular}{|c|c|c|}
\hline Item & Frequency & Percentage $\%$ \\
\hline \multicolumn{3}{|l|}{ Gender } \\
\hline Male & 141 & 47.0 \\
\hline Female & 159 & 53.0 \\
\hline \multicolumn{3}{|l|}{ Age } \\
\hline $15-20$ & 27 & 9.0 \\
\hline $21-25$ & 72 & 24.0 \\
\hline $26-30$ & 41 & 13.7 \\
\hline $31-35$ & 29 & 9.7 \\
\hline $36-40$ & 11 & 3.7 \\
\hline $41-45$ & 22 & 7.3 \\
\hline $46-50$ & 54 & 18.0 \\
\hline 51 years and above & 44 & 14.7 \\
\hline \multicolumn{3}{|l|}{ Occupation } \\
\hline Government sector & 18 & 6.0 \\
\hline Private sector & 213 & 71.0 \\
\hline Unemployed & 16 & 5.3 \\
\hline Student & 53 & 17.7 \\
\hline \multicolumn{3}{|l|}{ Marital status } \\
\hline Single & 92 & 30.7 \\
\hline Married & 201 & 67.0 \\
\hline Divorced & 7 & 2.3 \\
\hline \multicolumn{3}{|l|}{ Family income } \\
\hline Less than RM1000 & 21 & 7.0 \\
\hline RM1001-RM2000 & 33 & 11.0 \\
\hline RM2001-RM3000 & 50 & 16.7 \\
\hline RM3001-RM4000 & 71 & 23.7 \\
\hline$>$ RM4001 & 125 & 41.7 \\
\hline \multicolumn{3}{|l|}{ Race } \\
\hline Malay & 175 & 58.3 \\
\hline Chinese & 66 & 22.0 \\
\hline Indian & 57 & 19.0 \\
\hline Others & 2 & 7 \\
\hline \multicolumn{3}{|l|}{ Religion } \\
\hline Islam & 177 & 59.0 \\
\hline Buddha & 57 & 19.0 \\
\hline Hindu & 43 & 14.3 \\
\hline Christian & 23 & 7.7 \\
\hline Others & 0 & 0 \\
\hline \multicolumn{3}{|l|}{ Frequency } \\
\hline Every day & 84 & 28.0 \\
\hline Once a week & 58 & 19.3 \\
\hline Twice a week & 56 & 18.7 \\
\hline Thrice a week & 29 & 9.7 \\
\hline Others & 73 & 24.3 \\
\hline
\end{tabular}

Data Screening-assumptions for carrying out regression: The use of univariate normality of each variable was tested by examining the skewness and kurtosis value (Hair et al., 2010). The arithmetic mean is a good descriptor if the skewness value obtained is within \pm 2.0 cut off point set by George and Mallery's (2003). For kurtosis, the cutoff point less than 7 is acceptable (Byrne, 2009). In this study, the 
skewness and kurtosis values indicated the data was normal. Since the variables were all normally distributed, therefore it assumed that the regression analysis could be employed.

Correlation analysis: Table 2 shows the correlation between the acceptances of halal product with the intention of purchase. Overall, the was positive significant correlation between these two variables. The acceptance factors of halal products in this study were the cleanliness of restaurant, use of halal logo, dealer/operator, employee, ingredients, food preparation, government role, and intention of purchase. The results of correlation analysis between the cleanliness of restaurant and intention of purchase showed no significant relationship $(r=0.035, p=.541)$. The results also showed positive and significant correlation between the use of halal logo and intention of purchase $(r=0.305, p<0.01)$, as well as the correlation between dealer/operator and intention of purchase $(r=0.337, p<0.01)$. The employee factor has the strongest correlation with the intention of purchase $(r=0.425, p<0.01)$. Results also showed that the ingredients have significant correlation with the intention of purchase $(r=0.405, p<0.01)$. While, food preparation has lower significant correlation with the intention of purchase $(r=0.170, p<$ $0.01)$. Finally, the role of government was also correlated with the intention of purchase $(r=0.355, p<$ $0.01)$.

Table 2: Correlation Analysis

\begin{tabular}{lll}
\hline Independent Variables & $\boldsymbol{r}$ & $\boldsymbol{p}$ \\
\hline Cleanliness of Restaurant & $.035^{* *}$ & .541 \\
Use of Halal Logo & $.305^{* *}$ & .000 \\
Dealer/Operator & $.337^{* *}$ & .000 \\
Employee & $.425^{* *}$ & .000 \\
Ingredients & $.405^{* *}$ & .000 \\
Food Preparation & $.170^{* *}$ & .003 \\
Government Role & $.355^{* *}$ & .000 \\
\hline
\end{tabular}

** Correlation is significant at the 0.01 level (correlation of 2 variables)

* Correlation is significant at the 0.05 level (correlation of 2 variables)

Multiple Linear Regression Analysis: Table 3 shows the analysis using Stepwise regression. This analysis showed that the employee factor was inserted in Model 1, followed by government role added in Model 2, cleanliness factor in Model 3, while Model 5 was used for dealer/operator factor. Finally, the test in Model 5 showed ingredients factor was added in the model. Results showed that the five variables namely employee, government role, cleanliness of restaurant, dealer/operator and ingredients influenced the intention of purchase in all models. As depicted in the coefficients table (see Table 3), the estimation of the model coefficients for constant was 2.624. In Model 5, result showed that the employee has significant influence to the intention of purchase $(\beta=0.828, p<.01)$. The effect of government role and intention of purchase were also statistically significant $(\beta=0.242, p=.014)$. Cleanliness of restaurant was found to be negatively affected the intention of purchase $(\beta=-0.974, p<.01)$.The statistic has significant effect on dealer/operator on intention of purchase $(\beta=.146, p<0.01)$. Finally, the effect of ingredients on intention of purchase was also statistically significant $(\beta=0.63, p=0.019)$.

Overall, users agreed that factors of employee, government role, and cleanliness of restaurant, dealer/operator and ingredients used were the factors that have influenced the intention of respondents to purchase. However, the negative finding between the cleanliness of restaurant and intention of purchase showed that the respondents were not emphasizing the cleanliness factor as long as the food served come from lawful sources. Results also showed that the employee factor was the most important to influence the intention of customer to purchase. This meant that the customers were observing the employee either Muslim or non-Muslim as to encourage the customer to purchase. Based on Table 3, the Multicollinearity diagnostic obtained show tolerance value bigger tan 0.10 , while the value of statistic VIF was less than 10.0. This indicated that there was no serious problems from the multicollinearity between the predictor variable of studied model (Hair et al., 2010; Tabachnick \& Fidell, 2001). 
Table 3: Multiple linear regression analysis

\begin{tabular}{|c|c|c|c|c|c|c|c|c|c|c|}
\hline \multirow[t]{2}{*}{ Model } & \multicolumn{2}{|c|}{$\begin{array}{l}\text { Ununiform } \\
\text { coefficient }\end{array}$} & \multirow{2}{*}{$\begin{array}{l}\text { Uniform } \\
\text { coefficient } \\
\text { Beta }\end{array}$} & \multirow[t]{2}{*}{$\mathbf{t}$} & \multirow[t]{2}{*}{ Sig. } & \multicolumn{3}{|c|}{ Correlation } & \multicolumn{2}{|c|}{ Collinearity statistic } \\
\hline & B & $\begin{array}{l}\text { Standard } \\
\text { error }\end{array}$ & & & & $\begin{array}{l}\text { Zero- } \\
\text { order }\end{array}$ & Partial & Section & Tolerance & VIF \\
\hline $\begin{array}{c}1 \text { (Constant) } \\
\text { Employee }\end{array}$ & -.002 & $\begin{array}{l}.924 \\
.101\end{array}$ & .426 & $\begin{array}{l}-.002 \\
8.035\end{array}$ & $\begin{array}{l}.998 \\
.000\end{array}$ & .426 & .426 & .426 & 1.000 & 1.000 \\
\hline $\begin{array}{l}2 \text { (Constant) } \\
\text { Employee } \\
\text { Government role }\end{array}$ & $\begin{array}{l}-2.275 \\
.672 \\
.381\end{array}$ & $\begin{array}{l}1.010 \\
.101 \\
.101\end{array}$ & $\begin{array}{l}.353 \\
.255\end{array}$ & $\begin{array}{l}-2.252 \\
6.629 \\
4.778\end{array}$ & $\begin{array}{l}.025 \\
.000 \\
.000\end{array}$ & $\begin{array}{l}.426 \\
.355\end{array}$ & $\begin{array}{l}.362 \\
.270\end{array}$ & $\begin{array}{l}.339 \\
.244\end{array}$ & $\begin{array}{l}.919 \\
.919\end{array}$ & $\begin{array}{l}1.088 \\
1.088\end{array}$ \\
\hline $\begin{array}{l}3 \text { (Constant) } \\
\text { Employee } \\
\text { Government role } \\
\text { Cleanliness of } \\
\text { Restaurant }\end{array}$ & $\begin{array}{l}3.220 \\
.993 \\
.456 \\
-.941\end{array}$ & $\begin{array}{l}1.379 \\
.113 \\
.077 \\
.169\end{array}$ & $\begin{array}{l}.522 \\
.305 \\
-.330\end{array}$ & $\begin{array}{l}2.335 \\
8.830 \\
5.921 \\
-5.561\end{array}$ & $\begin{array}{l}.020 \\
.000 \\
.000 \\
.000\end{array}$ & $\begin{array}{l}.426 \\
.355 \\
.051\end{array}$ & $\begin{array}{l}.460 \\
.328 \\
-.310\end{array}$ & $\begin{array}{l}.430 \\
.288 \\
-.271\end{array}$ & $\begin{array}{l}.676 \\
.891 \\
.670\end{array}$ & $\begin{array}{l}1.479 \\
1.123 \\
1.492\end{array}$ \\
\hline $\begin{array}{l}4 \text { (Constant) } \\
\text { Employee } \\
\text { Government role } \\
\text { Cleanliness of } \\
\text { restaurant } \\
\text { Dealer/operator }\end{array}$ & $\begin{array}{l}2.938 \\
.928 \\
3.78 \\
-.938 \\
.146\end{array}$ & $\begin{array}{l}1.362 \\
.113 \\
.080 \\
.167 \\
.047\end{array}$ & $\begin{array}{l}.488 \\
.253 \\
-.329 \\
.165\end{array}$ & $\begin{array}{l}2.157 \\
8.221 \\
4.719 \\
-5.625 \\
3.113\end{array}$ & $\begin{array}{l}.032 \\
.000 \\
.000 \\
.000 \\
.002\end{array}$ & $\begin{array}{l}.426 \\
.355 \\
.051 \\
.337\end{array}$ & $\begin{array}{l}.435 \\
.267 \\
-.314 \\
.180\end{array}$ & $\begin{array}{l}.394 \\
.226 \\
-.270 \\
.149\end{array}$ & $\begin{array}{l}.653 \\
.802 \\
.670 \\
.819\end{array}$ & $\begin{array}{l}1.532 \\
1.247 \\
1.492 \\
1.221\end{array}$ \\
\hline $\begin{array}{l}5 \text { (Constant) } \\
\text { Employee } \\
\text { Government role } \\
\text { Cleanliness of } \\
\text { restaurant } \\
\text { Dealer/operator } \\
\text { Ingredients }\end{array}$ & $\begin{array}{l}2.624 \\
.828 \\
.242 \\
-.974 \\
.146 \\
.308\end{array}$ & $\begin{array}{l}1.358 \\
.120 \\
.098 \\
.166 \\
.047 \\
.130\end{array}$ & $\begin{array}{l}.435 \\
.162 \\
-.342 \\
.165 \\
.167\end{array}$ & $\begin{array}{l}1.932 \\
6.919 \\
2.466 \\
-5.862 \\
3.131 \\
2.367\end{array}$ & $\begin{array}{l}.054 \\
.000 \\
.014 \\
.000 \\
.002 \\
.019\end{array}$ & $\begin{array}{l}.426 \\
.355 \\
.051 \\
.337 \\
.406\end{array}$ & $\begin{array}{l}.378 \\
.144 \\
-.326 \\
.181 \\
.138\end{array}$ & $\begin{array}{l}.329 \\
.117 \\
-.279 \\
.149 \\
.113\end{array}$ & $\begin{array}{l}.572 \\
.526 \\
.664 \\
.819 \\
.113\end{array}$ & $\begin{array}{l}1.750 \\
1.900 \\
1.505 \\
1.221 \\
2.212\end{array}$ \\
\hline
\end{tabular}

Discussion: Consumers really care about hygiene in food preparation in the restaurants. However, the use of the halal logo and halal certificate are the most important factors for respondents in food selection at the restaurant. Ingredients used in cooking also between central consideration for respondents other than employee factors, hygiene and comfort of dining in the restaurant. These findings supported the views of Golnaz (2009), Fayyal \& Kamran (2011) and Mohani et al. (2009), which stated that Muslim users are more concerned with halal products and seek for halal products through the element found in food items. In addition, users also expect the use of the halal logo on food packaging so as not to cause confusion. It is well known that the purity of food is very important because it not only gives implications for the human being in this world but also in the hereafter. Self-construction of the individual is also influenced by the purity of food consumed. Hence, the question of halal and haram are things that cannot be taken for granted.

Islamic businesses need to intensify efforts to form a global partnership network that covers the aspects of food processing, marketing, provision of capital and research and development. While, Islamic financial institutions also need to have concomitant growth of the industry through the provision of flexible finance to potential entrepreneurs to thrive. The Government has established various rules to curb the abuse towards Muslim consumers, including introducing the Malaysian Halal Certification to all domestic and foreign goods. It is open to all food operators who are interested and have been obliged to obtain the halal certification and logo mark issued by the Malaysian Islamic Development Department (JAKIM) with the support of the Ministry of Domestic Trade and Consumer Affairs Commission (KPDNHEP) and state departments of Islam. The halal certification has now been further strengthened by obtaining the MS ISO 150002004 (Abang Sulaiman, 2006). Non-Muslims also enjoy the advantages of halal products with branding as confidence in the cleanliness and quality of the product compared to similar products but do not have a logo and halal certification. Furthermore, provision of halal food in food premises usually involves the principles and obligations of a Muslim himself. Every restaurant owner should prepare themselves in not only food preparation, but also need to know in detail about halal food and the unlawfulness of a food (Solehatun Naqiyah, 2009).

\section{Conclusion and Recommendations}

In general, consumer behavior towards acceptance of products is high. The users are very highly concerned about food preparation factors ordered should be from legitimate sources and the frequency of people in Lembah Pantai visited the restaurants was every day. Even though the cleanliness of the restaurant is one of the factors that influence the respondents in the selection of restaurants but respondents were more concerned with the food provided is from a lawful and clean sources. This 
reflected that the content and preparation of the food ingredients would influence the selection of restaurants. The government efficiency in ensuring that every restaurant is displaying the legitimate halal certificate and logo are very important to increase consumer trust to the restaurant. Although it is difficult for users to ensure that the halal certificate and logo displayed are valid, caution in selection of restaurants and awareness of hygiene and purity of food provided by local restaurants should be practiced by users. In this context, the role of government is crucial in ensuring the provision of halal certificate and logo only awarded to whom truly follows the guidelines prescribed. This can increase consumer confidence to the restaurants visited by them. It is well known that the purity of food is very important because it not only gives implications for the human being in this world but also in the hereafter. Self-construction of the individual is also influenced by the purity of food consumed. Hence, the question of halal and haram are things that cannot be taken for granted. Today, there is no doubt that the position of halal brand has now become very important in the food industry in Malaysia and global level. Therefore, future studies should be continued, as the halal food industry is an economic sector that has the potential to be a catalyst for strengthening the global network of Islamic business and trade community. In addition, Malaysia is also known as a world leading producer of halal food with an annual export value reaching RM5 billion, able to export processed food products to 80 countries.

\section{References}

Abang-Sulaiman, A. S., Mohd-Amran, H. \& Wan-Ariffin, W. Y. (2006). Persepsi, kesedaran dan tindakan masyarakat Islam terhadap makanan berasaskan daging ayam halal-Kajian kes di Kuching, Sarawak. Projek Penyelidikan. Universiti Teknologi MARA, Shah Alam.

Abdul-Basit, S. D. \& Sahilah, M. R. (2010). Persepsi Pelajar Fakulti Pendidikan Terhadap Makanan Berlogo Halal. Universiti Teknologi Malaysia, 1-8. (Unpublished).

Ajzen, I. \& Fishbein, M. (1980). Understanding attitudes and predicting social behavior .Englewood Cliffs. NJ: Prentice. Hall.

Arshia, M. \& Muhammad, M. B. (2011). Intention to choose Halal products: the role of religiosity. University Islamabad, Pakistan. Journal of Islamic Marketing, 3(2), 108-120.

Baron, R. M. \& Kenny, D. A. (1986). This moderator-mediator variable distinction in social psychological research: Conceptual, strategic, and statistical considerations. Journal of Personality and Social Psychology, 51(6), 1173-1182.

Berita Harian. (2006). Berita Harian, 9 Mei 2006.

Berita Harian. (2005). Berita Harian, 30 July 2005.

Byrne, B. M. (2009). Structural equation modelling with AMOS: Basic concepts, applications, and programming ( $2^{\text {nd }}$ Ed.). Mahwah, NJ: Lawrence Erlbaum.

Dayang-Aniza, A. H. (2012). Aplikasi konsep halal dalam kalangan pengusaha restoran Melayu di Johor Bharu. Tesis Sarjana Muda. Universiti Teknologi Malaysia, Johor.

Engku-Norma, E. A. (2009). Penyelidikan tahap penerimaan pengguna Islam di kalangan pelajar Universiti Malaysia Sabah (UMS) terhadap logo halal yang dilabelkan pada produk berasaskan coklat. Latihan Ilmiah Sarjana Muda. Universiti Malaysia Sabah.

Faryal, S. \& Kamran, S. (2011). Interdisciplinary Journal of Contemporary Research in Business. An Exploratory study for measuring consumers' awareness and perception towards halal food in Pakistan. University of Bradford, 3(2), 108-120.

Foster, D. P., Stine, B. \& Waterman, R. (1998). Business analysis using regression: A casebook. SpringlerVerlag.

George, D. \& Mallery, P. (2003). SPSS for Windows: Step by Step, (4th Ed). Pearson Education Inc: The United States of America.

Golnaz, R., Zainal, A. M. \& Mad-Nasir, S. (2010). Non-Muslim Consumer's Understanding Of Halal Principles in Malaysia. Universiti Putra Malaysia. Journal of Islamic Marketing, 3(1), 35-46.

Golnaz, R., Zainal, A. M., Mad-Nasir, S. \& Eddie-Chew, F. C. (2009). Economic and Technology Management Review. Concern of Halalness of Halal-Labelled Food Product among Muslim Consumer in Malaysia. Evaluation Selected Demographic Factors, 4, 65-73.

Hair, J., Black, W., Babin, B. \& Anderson, R. (2010). Multivariate data analysis (Seventh Ed.). New Jersey: Prentice-Hall. Inc.

Kementerian Perdagangan Dalam Negeri, Koperasi \& Kepenggunaan. (2013). Garis panduan dan kod etika industri restoran. Putrajaya.

Lili, S. (2006). Analisis Pengaruh Label Halal Terhadap Brand Switching (Produk Kosmetik Wardah). Institut Pertanian Bogor. Ref No. H24102118. 
Mohani, A., Hashanah, I., Haslina, H. \& Juliana, J. (2009). Consumer decision making process in shopping for halal food in Malaysia. Universiti Putra Malaysia. Serdang, 8(9) (Serial No. 75).

Mohd-Rizaimy, S., Jacqueline, J. P., Suhardi, W. M., Shamsul, J. E. \& Daing, M. S. (2010). International Journal of Marketing Studies. Purchase Intention of Organic Food in Kedah, Malaysia; a Religious Overview. Universiti Teknologi Mara, 2(1).

Persatuan Pengguna Pulau Pinang. (2006). Panduan Persatuan Pengguna Pulau Pinang: Halal-Haram. Pulau Pinang: PersatuanPengguna.

Produk Kosmetik Wardah. Institut Pertanian Bogor. Ref No. H24102118.

Solehatun, N. A. M. (2009). Mengkaji Sama ada aspek halal merupakan faktor utama dalam penyediaan makanan oleh para pengusaha premis makanan di kawasan zon 1 Bandar Kota Kinabalu Sabah. Latihan Ilmiah Sarjana Muda. Universiti Malaysia Sabah.

Syed, S. A. (2011). International Journal of Commerce and Management. Applying the Theory of Planned Behavior (TPB) in halal food purchasing. Universiti Kebangsaan Malaysia, 21(1).

Suddin, L., Geoffrey, H. T. \& Hanudin, A. (2009). Predicting Intention to Choose Halal Product Using Theory of Reasoned action. Universiti Malaysia Sabah, Sabah, Malaysia. International Journal of Islamic and Middle Eastern Finance and Management, 2(1), 66-76.

Tabachnick, B. G. \& Fidell, L. S. (2001). Using multivariate statistics. Sydney: Allyn \& Bacon.

Utusan Malaysia (2012).Utusan Malaysia, 29 September 2012.

Utusan Malaysia (2008).Utusan Malaysia, 5 Mei 2008.

Yaacob, M. R. (2008). SPSS for business and social science students. Malaysia: Pustaka Aman Press Sdn. Bhd. 